\title{
FACTORS OF REGIONAL TOURIST MARKET FORMATION IN SUMY REGION AND ITS PLACE IN THE NATIONAL TOURIST MARKET OF UKRAINE
}

\author{
Alina BERESTOK \\ Taras Shevchenko National University of Kyiv, Ukraine \\ berestokalina@gmail.com
}

\begin{abstract}
The article analyzes the status and trends of tourism in Sumy region, identifies the basic factors of formation and functioning of the tourism market in the region. There was investigated existing and prospective tourist product in Sumy region and its information support. As a result, it was identified the place of the Sumy regional tourism market in the national tourist market of Ukraine.
\end{abstract}

Key words: tourism market, regional tourism market, factors of market.

UDC: 910.1

\section{ФАКТОРИ ФОРМУВАННЯ РЕГІОНАЛЬНОГО ТУРИСТИЧНОГО РИНКУ СУМЩИНИ ТА ЙОГО МІСЦЕ НА НАЦІОНАЛЬНОМУ ТУРИСТИЧНОМУ РИНКУ УКРАЇНИ}

\author{
Аліна БЕРЕСТОК \\ Київський національний університет імені Тараса Шевченка, Україна \\ berestokalina@gmail.com
}

\begin{abstract}
Анотація: У статті проведено аналіз стану та тенденції розвитку туристичної діяльності у Сумській області, визначені основні фактори формування та функціонування ринку туристичних послуг регіону. Досліджено наявний та перспективний турпродукт Сумщини, його інформаційне забезпечення. Визначено місце регіонального туристичного ринку області на національному туристичному ринку України.
\end{abstract}

Ключові слова: ринок туристичних послуг, регіональний туристичний ринок, фактори формування ринку.

УдК: 910.1

Вступ. Постановка проблеми. Туризм $€$ багатоплановою діяльністю, що присутня в економічній, просторовій, суспільній та культурній сферах. Наразі туристична галузь, яка постійно та динамічно розвивається, відіграє істотну роль у стимулюванні господарського розвитку України, а також приносить суттєву вигоду окремим регіонам держави.

Сумська область має перспективи розвитку

(C) А. Бересток туризму на своїй території, адже характеризується значними туристично-рекреаційними можливостями, а за кількістю та складом історичних i архітектурних пам'яток випереджає деякі інші області. Тому туристична діяльність $є$ одним 3 пріоритетних напрямів підвищення ефективності функціонування регіону.

Проте, в умовах високого рівня конкуренції на ринку туристичних послуг, Сумщина не встигає за сучасними потребами та недостатньо використовує свої рекреаційні можливості. Тому сьогодні 
гостро стоїть питання щодо проблем дослідження регіонального туристичного ринку, а також факторів його формування та функціонування.

Аналіз останніх досліджень і публікацій. Дослідженню туристичної галузі та різноманітних аспектів ринку туристичних послуг присвячено роботи вітчизняних та зарубіжних вчених О.О.Любіцевої, О.О.Бейдика, М.І.Долішнього, В.Г.Герасименка, T. І.Ткаченко, В.Ф.Кифяка, I.М.Школи, В.І.Азара, Н.І.Кабушкіна, І.В.Зоріна та ін.

Формулювання цілей статті. Постановка завдання. Головною метою статті $є$ дослідження особливостей формування і функціонування ринку туристичних послуг Сумської області та визначення його місця на національному туристичному ринку. Для досягнення поставленої мети необхідно вирішити ряд завдань, а саме:

- провести аналіз термінологічного апарату у сфері регіонального туристичного ринку;

- дослідити фактори формування ринку туристичних послуг Сумської області;

- проаналізувати основні складові ринку туристичних послуг регіону;

- визначити тенденції розвитку регіонального туристичного ринку Сумщини, а також його місце на національному туристичному ринку України.

Виклад основного матеріалу.

Під поняттям ринку розуміємо взаємовідносини, що виникають внаслідок товарного обміну між постачальником та споживачами, рішення яких формує попит та пропозицію. Туристичний ринок $\epsilon$ видовим компонентом світового ринку послуг i виступає сферою задоволення потреб населення в послугах, пов'язаних із відпочинком та змістовним проведенням дозвілля у подорожі [5].

У сфері міжнародного туристичного обміну річний оборот складає понад 2 трлн дол США. В Україні туристичний ринок знаходиться у стадії розвитку. За даними Всесвітньої туристичної організації (UNWTO) частка прямих надходжень від туристичної сфери до ВВП України становить 1,5 2,5\% [11]. Це свідчить про недостатньо ефективне функціонування ринку туристичних послуг, який включає послуги розміщення, харчування, транспортування, екскурсійного обслуговування та супутніх послуг, які сприяють повній реалізації мети подорожі.

На даний час актуальним питанням залишається дослідження регіональних особливостей туристичного ринку України. Під регіональним ринком туристичних послуг слід розуміти систему стійких взаємовідносин між виробником i споживачем туристичного продукту, інтереси яких реалізуються в межах певної території.

На формування регіонального туристичного ринку впливає ряд факторів, котрі мають різну ступінь впливу. До основних ринкоутворюючих факторів туризму Сумської області можна віднести:

- кліматичні та фізико-географічні умови (особливості використання природних та кліматичних ресурсів, техногенні фактори, стан атмосферного повітря, якість води тощо);

- рівень соціально-економічного розвитку регіону (демографічні показники, зайнятість населення, рівень освіти громадян, грошові доходи та прожитковий мінімум населення тощо);

- культурно-історичні фактори;

- наявність інфраструктури туризму.

Сумська область має сприятливі кліматичні умови та природно-рекреаційний потенціал, який характеризується наявністю різноманітних ландшафтних та водних ресурсів. Сумщина $\epsilon$ регіоном, де природна рослинність збереглась на значних площах. За даними Департаменту екології, паливно-енергетичного комплексу та природних ресурсів Сумської обласної державної адміністрації станом на 1 січня 2014 року загальна площа природнозаповідного фонду становить 176506,4 га, показник заповідності дорівнює 7,4\% [1]. На території області протікає 165 річок довжиною більше 10 км і 2115 річок

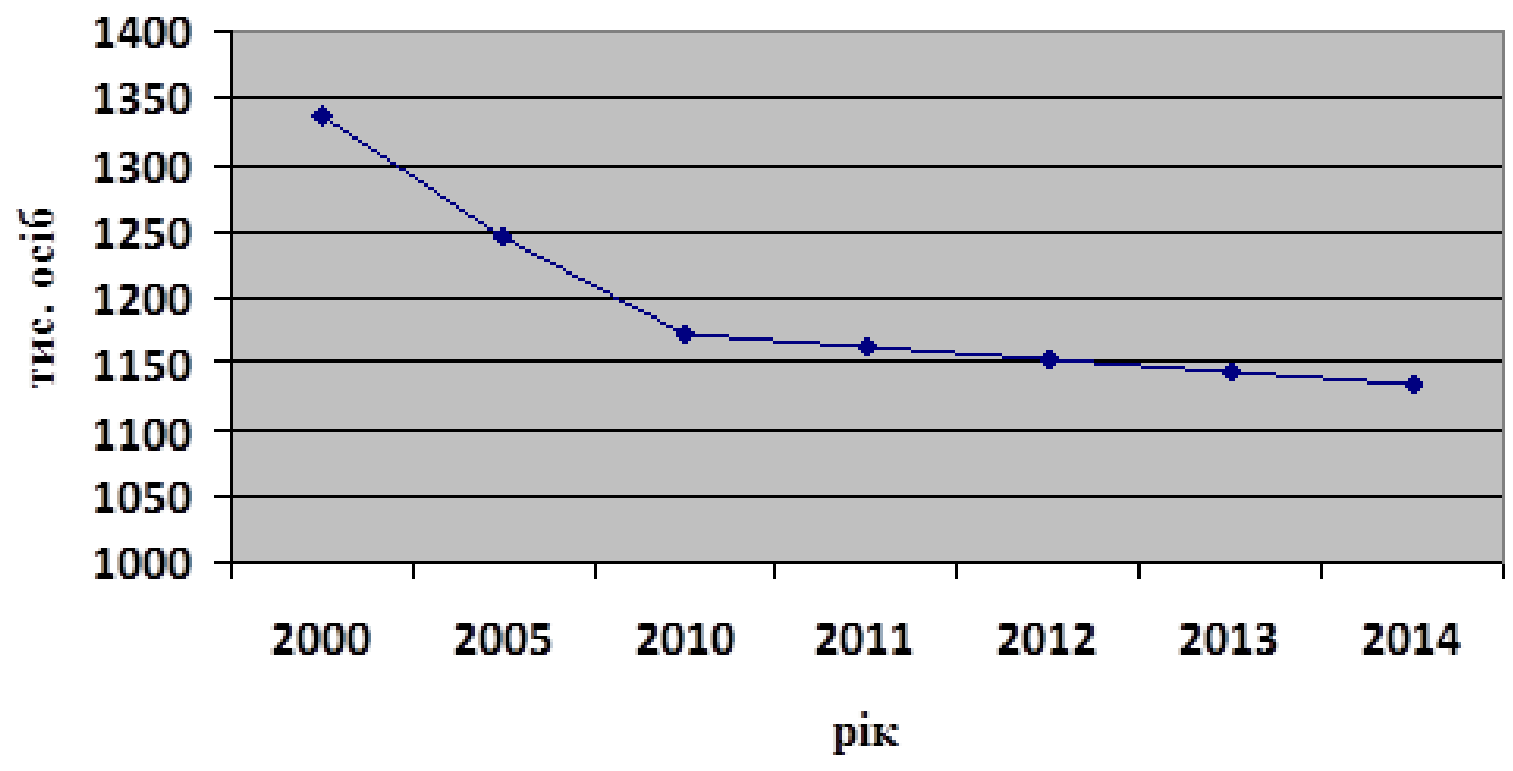

Рис. 1. Чисельність наявного населення у Сумській області [3] 
довжиною менше 10 км. Найбільші річки (Десна, Сейм, Сула, Псел і Ворскла) освоєні в рекреаційному відношенні [12]. Наявність даних факторів $є$ підставою формування на території області пізнавальнооздоровчого та пляжно-купального відпочинку, а також водного туризму.

Характеризуючи рівень соціально-економічного розвитку Сумщини варто звернути увагу на основні демографічні показники. За даними Головного управління статистики у Сумській області в останні роки спостерігається тенденція зменшення кількості населення (рис. 1).

Зменшення кількості населення відбувається в результаті як природного скорочення, так $\mathrm{i}$ міграційного. Чисельність населення обумовлює безпосередньо обсяг споживчого сектора туризму. Проте негативна динаміка кількості населення характерна для більшості областей України.

У 2014 році частка номінальних доходів населення області склала 2,3\% у загальному обсязі доходів населення України, і становили 35530 млн. грн. Основними джерелами формування доходів населення області $є$ заробітна плата та соціальні допомоги, що становить 57,9\% їх загального обсягу. історичних ресурсів формує їі позитивний туристський імідж та урізноманітнює рекреаційнотуристьку пропозицію. Наприклад, 3 метою популяризації туризму на Сумщині було виділено сім найцікавіших історико-культурних пам'яток регіону, до яких ввійшли: пам'ятник мамонту у с. Кулішівка Недригайлівського району, «Круглий двір» у Тростянці, комплекс Софроніївського монастиря у Путивльському районі, група Посульських курганів у Роменському районі, Трьох-Анастасіївська церква у Глухові, поле Конотопської битви (1659 рік, с. Шаповалівка Конотопського району), СвятоПокровський собор у Охтирці [4]. Із вищесказаного можна зробити висновок, що у Сумській області $€$ унікальні пам'ятки історії та культури, які можна застосовувати для організації різних видів пізнавального туризму.

Одним із основних факторів формування та функціонування туризму в регіоні $\epsilon$ наявність інфраструктури туризму (засоби розміщення, наявність розважальних місць, транспортна інфраструктура і засоби комунікації тощо).

Розвиток готельної індустрії $є$ однією із головних складових туристичної галузі (табл. 1).

Таблиия 1

Готелі та аналогічні засоби розміщування

\begin{tabular}{|l|c|c|c|c|c|c|c|}
\hline & 2000 & 2005 & 2010 & 2011 & 2012 & 2013 & 2014 \\
\hline Кількість готелів та аналогічних засобів розміщування & 46 & 44 & 36 & 48 & 47 & 50 & 41 \\
\hline Кількість номерів & 898 & 842 & 1070 & 828 & 806 & 1757 & 1736 \\
\hline Кількість місць & 2372 & 2054 & 2925 & 1419 & 1611 & 1473 & 1452 \\
\hline Обслуговано приїжджих, тис.осіб & 59,5 & 67,2 & 48,2 & 56,3 & 49,6 & 50,9 & 45,1 \\
\hline
\end{tabular}

Складено за матеріалами [9]

Реальний наявний дохід населення, визначений 3 урахуванням цінового фактора (індексу інфляції), зменшився на $6,9 \%$ в порівнянні з попереднім роком, в цілому по Україні - на $8,4 \%$.

Середньомісячний наявний дохід у розрахунку на одну особу населення за 2014 рік склав 2058 грн., що на $10,8 \%$ менше від середнього показника по Україні.

Витрати населення у 2014 році становили 30826 млн.грн., переважну частину витрат населення становили витрати на придбання товарів та послуг (79,2\%). Приріст заощаджень склав 4704 млн.грн. [6].

Із 2006 року у Сумській області наявно 10 вищих навчальних закладів I-II рівнів акредитації, в яких в середньому навчається близько 5 тисяч студентів, та 5 BHЗ III-IV рівнів акредитації із близько 45 тис. студентів в середньому [3].

На формування туризму в Сумській області також впливають історико-культурні фактори, зокреманаявність історико-культурних рекреаційних ресурсів, адже вони виконують важливі виховні функції та мають велике значення для психологічного оздоровлення. В регіоні налічується майже 1,5 тис. пам'яток історії, 780 археології, 102 пам'ятники монументального мистецтва та 373 пам'ятки архітектури [3].

Розташування на території області суспільно-
Характеризуючи статистичні дані щодо готельної інфраструктури у Сумській області, варто зазначити наступну динаміку іiі розвитку: у 2014 році в порівнянні з 2013 роком кількість готелів та аналогічних засобів розміщення зменшилася. Упродовж 2014 року в області працювало 50 готелів та аналогічних засобів розміщування (у т.ч. турбази, студентські літні табори), в 2013 їх кількість налічувала 50 . В свою чергу зменшилася кількість приїжджих близько на $10 \%$.

Якщо брати до уваги місце Сумської області за кількістю колективних закладів розміщення серед інших областей України, то у 2014 році даний регіон займає 23 місце. Частка готельних підприємств регіону в загальнонаціональному масштабі постійно знижується - 3 3,6\% у 2005 р. до 1,5\% у 2014 р.

Для більш ефективної оцінки готельної інфраструктури регіону необхідно розрахувати показник щільності готелів, тобто яка кількість місць у засобах розміщування припадає на 1000 жителів області. за даним показником можна проаналізувати рівень забезпеченості регіону готельними послугами. Отже, за власними розрахунками у 2014 році даний показник дорівнює 1,28 (середнє нормативне значення 10). Звідси можна зробити висновок, що Сумська область характеризується наявністю малої кількості - готельних комплексів та місць 
для відпочинку туристів. Основними проблемами розвитку готельної інфраструктури в регіоні є: нестабільність попиту на готельні послуги, низький рівень благоустрою та неналежний стан матеріальнотехнічної бази, падіння рентабельності тощо.

Важливу роль у розвитку туристичної галузі відіграє транспортна інфраструктура. За даними Служби автомобільних доріг у Сумській області довжина автодоріг загального користування становить 7,2 тис. км, 3 них 2,1тис. км - державні дороги, а 5,1 тис. км - місцевого значення. Тверде покриття мають 6,7 тис. км доріг, питома вага яких у загальній довжині дорівнює 93,1\%. Відношення частки доріг із твердим покриттям в області до значень по Україні складає 4\%.

Середня щільність автодоріг із твердим покриттям в регіоні становить 282 км шляхів на 1 тис.км² території.

Сумська область є прикордонною і має шість під’іздів до пунктів пропуску через державний кордон. Також Сумщину перетинає відгалуження транспортного коридору Критський № 9-міжнародна автомобільна дорога М 02 Кіпті - Глухів - Бачівськ, що є міжнародною магістраллюЕ 101. Вона проходить територією Кролевецького та Глухівського районів і має протяжність 97,6 км.

$1,4 \%$ доріг європейського та 29,2\% доріг національного значення від загальної довжини доріг області проходить по її території [8].

Дороги європейського значення сполучають такі об’єкти туристичного інтересу як місто Кролевець, що $є$ центром народних промислів, та місто Глухів, де збереглися архітектурні пам'ятки, зокрема такі церкви як Миколаївська, Трьох-Анастасіївська, Спасо-Преображенська та Вознесенська, а також Тріумфальні ворота, руїни Тюремного замку тощо.

Автомобільні дороги місцевого значення, в тому числі і у місцях, де пролягають туристичні маршрути, характеризуються невідповідністю сучасним транспортним навантаженням, низькою якістю, і потребують ремонтних робіт.

Рівень розвитку туризму в регіоні виражається туристичними потоками, тобто кількістю прибулих туристів у регіон або кількістю туристів, які виїхали за кордон за певний період часу (рис. 2).

За останні роки простежується тенденція зменшення загального туристичного потоку в області як за рахунок зниження в’їзного, так і внутрішнього туризму.

Аналізуючи інформацію обласного управління статистики, було виявлено тенденцію того, що пріоритетним напрямом туристичної діяльності впродовж 2014 року був виїзний туризм, на який припадало $67,6 \%$ потоку туристів. Частка внутрішнього туризму становила $32,1 \%$, а в'їзного туризму лише $0,3 \%$.

Аналізуючи графік, протягом останніх п’яти років простежується нерівномірний розподіл туризму за його видами. Максимальна кількість іноземних туристів прибули у Сумську область у 2010 році (203 особи), мінімальна - впродовж останніх двох років (25 осіб). Що стосується виїзного туризму, то найвищий показник кількості туристів-громадян України, які виїжджали за кордон становить 11992 тис. осіб у 2010 році, мінімальний - у 2005 році (3019 осіб).

Статистичні дані по Сумській області показують значну перевагу внутрішнього туризму, за виключенням 2014 року, де спостерігається перевага виїзного туризму. Максимальна кількість внутрішніх туристів була у 2010 році і становила 32977 осіб, мінімальна - 2751 особа у 2014 році (рис. 4).

Характеризуючи графік динаміки туристичних потоків по Україні, варто сказати, що в період з 2011 по 2013 роки на українському ринку збільшилася кількість внутрішніх туристів та туристів-громадян України, які виїжджали за кордон. За останні роки простежується зниження іноземного туризму, і перебуває він в середньому на рівні близько 30 тис. туристів на рік. Спад туристичних потоків у 2014 році можна пояснити тим, що дані надані без урахування території Автономної Республіки Крим, м.Севастополя та частини зони проведення антитерористичної операції.

Найвища частка туристів, обслужених туристичними операторами по Сумській області в розрізі країни, становила 1,98\% у 2010 році. В подальші роки було поступове зниження питомої ваги туристичних потоків в регіоні, і в 2014 році вона становила $0,35 \%$.

При аналізі туристичних потоків області було проведено парну кореляцію коливання потоків туристів 3 можливостями населення (середня заробітна плата, середній дохід населення, наявний та реальний дохід на 1 особу тощо). За допомогою кореляції можна встановити, чи є зв'язок між двома змінними та виміряти потужність і напрямок зв'язку між ними.

У результаті розрахунків було виявлено залежність між середньою заробітною платою населення та потоком туристів-громадян України, які виїжджали за кордон. Значення кореляції становить 0,5 , що характерно для позитивної лінійної кореляції, тобто при збільшенні заробітної плати - збільшується частка виїзного туризму.

Окремою частиною комплексу туристичних послуг є екскурсійна діяльність. Екскурсія - це методично продуманий показ визначних місць, пам'яток історії та культури, що базується на аналізі побачених об'єктів та розповіді про події, які пов'язані з ними [2].

Протягом останніх п'яти років суб'єктами туристичної діяльності Сумської області було обслуговано близько 14 тис. екскурсантів. (табл. 2).

3 таблиці видно, що починаючи з 2010 року відбувається поступове зниження чисельності екскурсантів на Сумщині. У порівнянні з 2013 p. кількість обслугованих екскурсантів у 2014 р. зменшилася на $20 \%$.

Основним регіональним туристичним продуктом на ринку туристичних послуг Сумської області є турпродукт пізнавального (екскурсійного), культурного, оздоровчого та релігійного туризму.

На території області налічується велика кількість унікальних історико-культурних об'єктів, природ- 


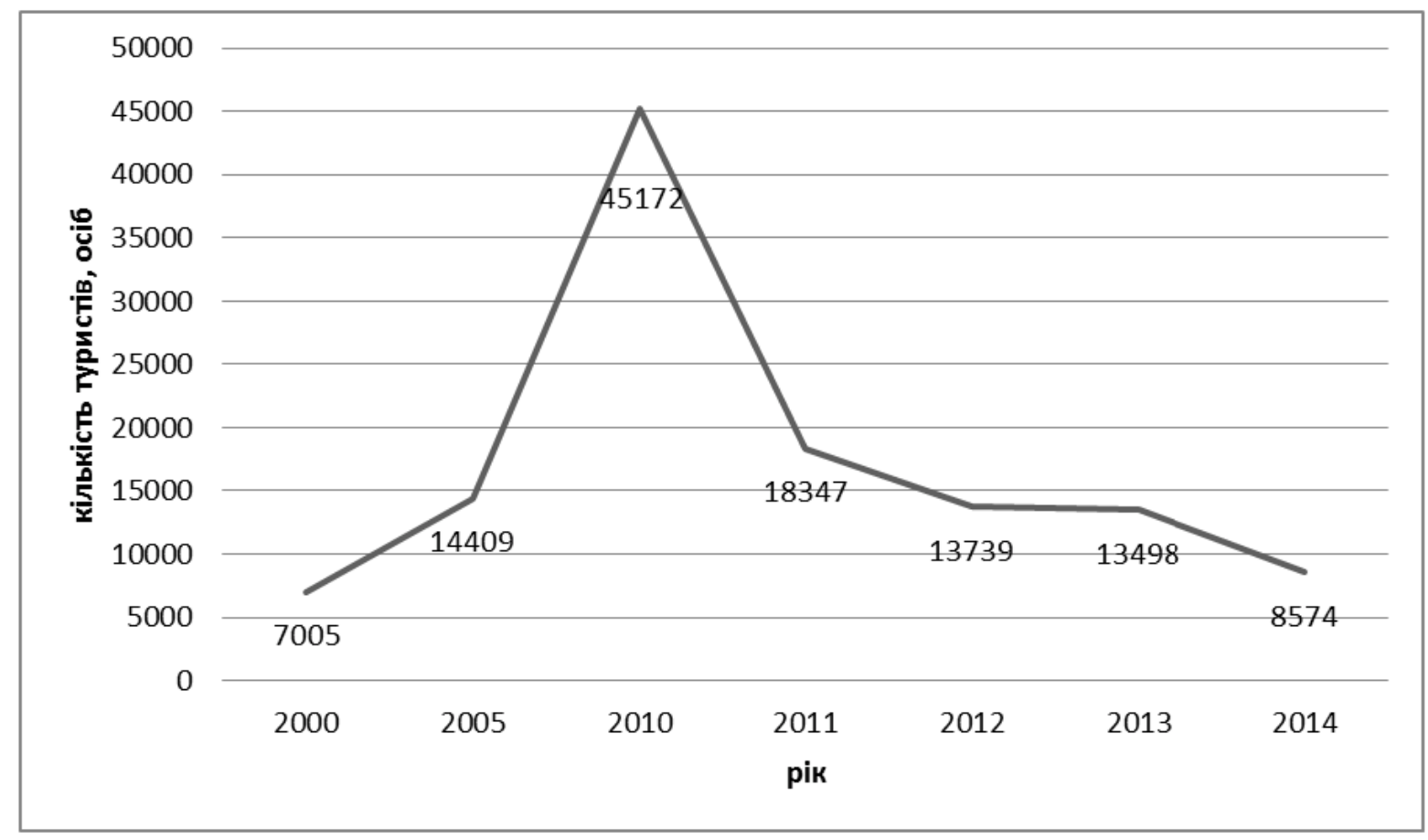

Рис. 2. Динаміка туристичних потоків по Сумській області [3]

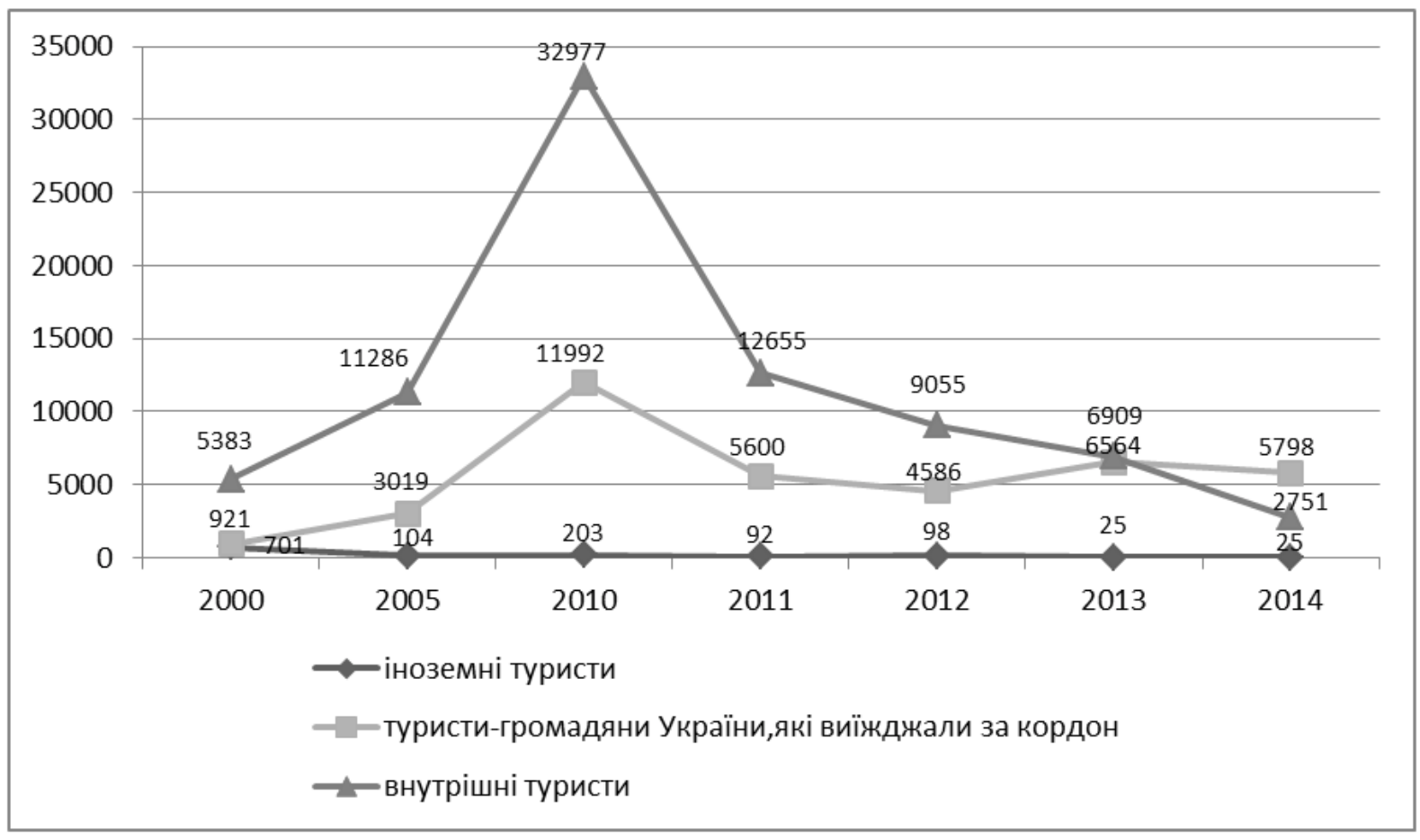

Рис. 3. Динаміка туристичних потоків за видами туризму в Сумській області [3]

Кількість екскурсантів у Сумській області

\begin{tabular}{|c|c|c|c|c|c|c|}
\hline \multicolumn{7}{|c|}{ Кількість екскурсантів, осіб } \\
\hline $\mathbf{2 0 0 0}$ & $\mathbf{2 0 0 5}$ & $\mathbf{2 0 1 0}$ & $\mathbf{2 0 1 1}$ & $\mathbf{2 0 1 2}$ & $\mathbf{2 0 1 3}$ & $\mathbf{2 0 1 4}$ \\
\hline 10004 & 14551 & 40788 & 12040 & 7828 & 3633 & 2908 \\
\hline
\end{tabular}

Складено за матеріалами [3] 


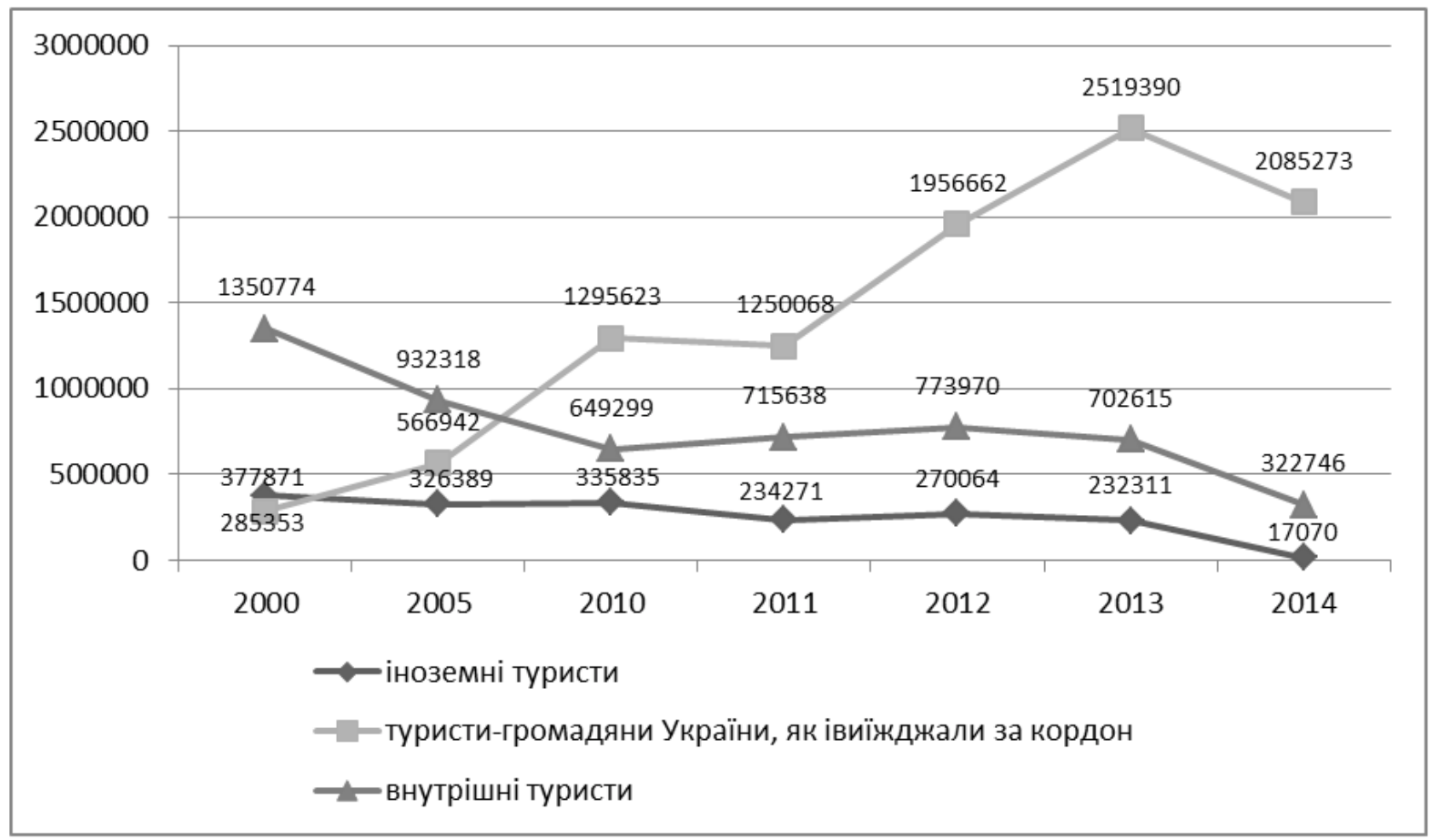

Рис. 4. Динаміка туристичних потоків по Україні [8]

них пам'яток, наприклад заповідник «Михайлівська цілина», Яблуня-колонія, Шелеховське озеро тощо, а також храмів та церков, які являються витворами архітектури, що в свою чергу приваблюють віруючих та туристів.

В регіоні є безліч туристичних агентств, які надають комплекс послуг у сфері пізнавального туризму. До одних з найбільш відомих належать: мережа туристичних агентств «Поїхали 3 нами», OОО «Aistur», турфірма «Рожева чайка». Ці туроператори проводять туристичну діяльність не лише в області, а й в Україні та за їі межами.

На Сумщині туристсько-екскурсійні послуги надають також туристичні компанії «Сумитурист», ООО «Агро», турфірма «Інтурист-Суми» тощо. Серед поширених послуг є проведення автобусних турів по території Сумської області з культурно-виховною і просвітницькою метою.

Регіональним тур продуктом $\epsilon$ послуги оздоровчого туризму. Сьогодні на Сумщині діють 26 дитячих оздоровчих таборів, 5 баз відпочинку, 6 санаторіїв-профілакторіїв, 2 санаторії (обласний дитячий багатопрофільний санаторій «Лебедин», санаторій «Токарі»), СПА-курорт «Буймерівка» [3].

Перспективним турпродуктом для Сумської області є сільський зелений туризм. Для забезпечення туристів якісними послугами у сільському туризмі Спілкою сприяння розвитку сільського туризму в Україні запроваджена система категоризації «Українська гостинна садиба», за якої Сумська область за рівнем розвитку має середньо-розвинений зелений туризм. У даному регіоні користуються попитом такі садиби сільського зеленого туризму як «Вакулина байка» у селі Бездрик, «Грунівка січ» у селі Барилівка, «Олександрія» у місті Шостка, «Північний ліс» у селі Жолдаки, «Хутір лісовий» у селі Новомутин, «Квітковий рай» у селі Кренидівка тощо. Основними послугами, якими пропонують скористатися в садибах Сумщини є: мисливство, риболовля, велосипедні та кінні прогулянки, а також можливість скуштувати українські страви, приготовлені з екологічно чистих продуктів [10].

Підвищення якості надання туристичних послуг, збільшення рівня інформованості споживачів про туристичні продукти та розширення обміну інформацією забезпечує інформаційна складова підприємств туристичної сфери.

Інформаційним забезпеченням туристичної діяльності в регіоні займається Інформаційнотуристичне видання Управління культури і туризму Сумської обласної державної адміністрації, яке випускає в друк книги, брошури, путівники, бюлетені з описом туристичних об'єктів області.

Також у 2004 році була створена Обласна туристична Асоціація «Сумщина Туристична», основними функціями якої є:

- надання інформації про культурні, спортивні, туристські заходи, що проводяться у регіоні;

- забезпечення інформаційно-довідковими виданнями, розповсюдження поліграфічної рекламної та інформаційної продукції;

- здійснення моніторингу ринку туристських можливостей міста та області на основі єдиного інформаційного банку даних суб'єктів туристичної діяльності;

- популяризація області й їі історичної культурної спадщини тощо [7].

Туристичні підприємства розміщують сайти в мережі Інтернет з інформацією про свою діяльність, також створені туристичні портали та форуми для рекламування регіонального туристичного продукту.

Сумська область має перспективи просування регіонального туристичного продукту на 
національному туристичному ринку, проте наразі існують проблеми розвитку туризму, які мають системний характер і притаманні більшості регіонам країни.

\section{Висновки і перспективи подалыших розвідок.}

В результаті дослідження регіонального туристичного ринку Сумської області виявлено основні фактори його формування та функціонування, до яких належать кліматичні та фізикогеографічні, соціально-економічні, культурноісторичні фактори та наявність інфраструктури індустрії туризму.

Однією 3 проблем розвитку туристичної діяльності в регіоні $€$ недостатня забезпеченість туристичною інфраструктурою. За кількістю засобів розміщення Сумська область посідає 23 місце серед інших областей України. Частка готельних підприємств регіону в загальнонаціональному масштабі становить лише 1,5\% у 2014 р.
Аналізуючи динаміку туристичних потоків, було виявлено тенденцію того, що пріоритетним напрямом туристичної діяльності в області є виїзний та внутрішній туризм.

Основним регіональним туристичним продуктом на ринку туристичних послуг Сумської області $\epsilon$ культурно-пізнавальний, оздоровчий та сільський зелений туризм.

Інформаційне забезпечення туристичної діяльності в регіоні в основному надають Асоціація «Сумщина Туристична» та Інформаційнотуристичне видання управління культури і туризму Сумської обласної державної адміністрації.

Отже, варто зазначити, що створення місцевого територіального ринку області на основі розбудови туристичної інфраструктури та інтенсифікації ресурсної бази туризму дасть поштовх для формування конкурентоспроможного національного туристичного продукту.

\section{References:}

1. Departament ekologï̈, prirodnih resursiv ta palivno-energetičnogo kompleksu [Department of Environment, Natural Resources and Energy Sector]. Available at: http://www.pek.sm.gov.ua/ (In Ukrainian).

2. Emel'ânov B. V. Èkskursovedenie. [Tour Guidance]. Moscow, 2007, 216 p. (In Russian).

3. Golovne upravlinnâ statistiki u Sums'kì oblastì [Department of Statistics in Sumy region]. Available at: http:// sumy.ukrstat.gov.ua/ (In Ukrainian).

4. News Agency RegioNews-Sumy. Available at: http://regionews.sumy.ua/ (In Ukrainian).

5. Klìmačov L. D. Sìm čudes Sumŝini: İnformacìno-bibliografičnij putìvnik [Seven Wonders of Sumy Region: Informational and bibliographical guidebook]. Sumy, 2007, 35 p. (In Ukrainian).

6. Lûbìceva O. O. Rinok turističnih poslug (geoprostorovi aspekti) [Market of tourist services (geospatial aspects)]. Kyiv, 2002, 436 p. (In Ukrainian).

7. Official site of the Regional Tourism Association "Touristic Sumy”. Available at: http://www.tourass.narod.ru/ (In Ukrainian).

8. Official site of the State Statistics Service of Ukraine. Available at: http://www.ukrstat.gov.ua/ (In Ukrainian).

9. Site "New Ecology". Available at: http://www.novaecologia.org/ (In Ukrainian).

10. Official site of the Union to Promote Rural Tourism in Ukraine. Available at: http://www.greentour.com.ua/ (In Ukrainian).

11. Official site of the World Tourism Organization. Available at: http://www2.unwto.org

12. Official site of the Road Service in Sumy region. Available at: http://su.ukravtodor.gov.ua/ (In Ukrainian). 